\title{
Tourism industry responses to public-private partnership arrangements for destination management organisations in small island economies: a case study of Jersey, Channel Islands
}

\author{
Samantha Chaperon \\ Department for Marketing, Events and Tourism, \\ University of Greenwich, \\ Old Royal Naval College, Greenwich, \\ SE10 9LS, London, England \\ Email: S.A.Chaperon@greenwich.ac.uk
}

\begin{abstract}
Since the 1970s, in many developed countries, governance arrangements for tourism have been revised in response to significant challenges faced by national economies and the associated changing political contexts. Destination management organisations (DMOs) that have traditionally been part of public-sector structures have been shifted towards the realm of the private sector and are now operated in a collaborative way, with public-private partnerships (PPPs). This paper takes a governance theory approach and examines tourism industry stakeholders' responses to a proposed public-private partnership arrangement for the local destination management organisation in Jersey, a British Isle. The period under study is 2006 to 2012, a time when public sector governance arrangements for tourism were experiencing significant change in the UK context. Stakeholders acknowledged and agreed the common benefits associated with PPPs, such as greater efficiencies and expertise, but they also identified in particular the various reasons why a standard PPP model would not be appropriate for Jersey's DMO because of the island characteristics of the destination. These stakeholders' responses to a new PPP model are better understood by examining the relationship between governance and the concept of 'islandness'.
\end{abstract}

Keywords: governance; tourism policy; public-private partnerships; PPPs; islands; islandness; destination management organisations; DMOs.

Reference to this paper should be made as follows: Chaperon, S. (xxxx) 'Tourism industry responses to public-private partnership arrangements for destination management organisations in small island economies: a case study of Jersey, Channel Islands', Int. J. Tourism Policy, Vol. X, No. Y, pp.xxx-xxx.

Biographical notes: Samantha Chaperon is a Principal Lecturer in Tourism and Events at the University of Greenwich Business Faculty. Her research interests include tourism governance, tourism in islands, destination management and tourism policy.

This paper is a revised and expanded version of a paper entitled 'Governance structures for tourism in small island economies. Case study: Jersey, Channel Islands' presented at International Conference on Tourism (ICOT), Archanes, Crete, 23-26 May 2012. 


\section{Introduction}

For many countries, government reform and restructuring is a common feature of today's political environment, and this has had a significant influence on the governance of tourism in these countries (Dredge and Jenkins, 2007). Since the 1970s, policy decisions have increasingly reflected neoliberal approaches, and for some sectors, including tourism, the state has become an increasingly less dominant influence (Richards and Smith, 2002; Hall, 1999). A concomitant preference for market-led forms of economic organisation and an increased emphasis on competitiveness and efficiencies has led to the need for new forms of local governance, often referred to as 'new governance' (Rhodes, 1996). In the UK, for instance, many governance structures have been devolved and now the state's activities are increasingly being carried out through 'at arm's length' relationships; this means a growing reliance on agencies and public-private partnerships (PPPs) to deliver government policy objectives in non-core aspects of government, such as the governance and development of tourism (Bramwell, 2011; Laws et al., 2011). These organisations can operate at varying levels of independence from government, but a key feature is the shift of decision making power, and financing, from the public to private and third sector actors (Bramwell and Lane, 2011). There is a relative paucity of research into the relationship between political shifts such as these and tourism policy and development (Mosedale, 2011) and this paper provides a contribution in this regard by using governance theory to critique changes in the mechanisms of tourism governance, through a case study. Governance theory is useful as it provides a political economy framework within which the changing processes of governing can be understood and is fundamental to the development of understanding of the relationships between public and private institutions for tourism (Hall, 2011).

This paper examines the changing governance arrangements for tourism in a small island economy (SIE) context. An SIE can be defined as an island with a total population of under 1.5 million (Commonwealth Secretariat, 1997). With a population of around 100,000, Jersey, a British Isle located in the English Channel, but not part of the UK, falls into this category and is used as a case study here. The focus for the study is limited to the period 2006 to 2012, a time when public sector governance arrangements for tourism were experiencing significant change in the UK context (Kennell, 2013; Kennell and Chaperon, 2013). A policy decision was taken by Jersey’s government in 2009 (States of Jersey, 2011a) to put into place a revised destination management organisation (DMO), and a public-private partnership (PPP) was proposed. This paper analyses tourism industry stakeholders' perceptions on whether a standard PPP model was considered appropriate for governing Jersey's tourism sector, or whether characteristics specifically associated with its island status has affected the opportunities for effective public-private collaboration and influenced the choice of funding and delivery mechanisms for the management and marketing of tourism at the destination.

\section{The changing role of government}

Government has traditionally been regarded as the dominant actor in the policy arena, with governing essentially seen as a process of one-way traffic from those governing (government) to those being governed (society) (Kooiman, 2000). However, for the more developed liberal democracies which have tended to follow capitalist economic paths, the 
role of the state has changed, with implications for the governance and development of tourism. In the period after the Second World War there was a great need and support for high levels of government intervention in areas such as welfare provision, rebuilding of essential infrastructure, and more broadly in revitalising economic growth. As part of this, some countries chose to nationalise industries where economic efficiencies could be achieved, such as transport, communications and energy. However, the economic growth that had been enjoyed during the post war period was not sustained and during the 1970s this highly interventionist style of governance became less desired by the electorate (Bramwell and Lane, 2010; Shone and Memon, 2008; Jessop, 2003). Since then, governments have redefined their roles and responsibilities and have changed in many cases from being a provider to an enabler, and from a top-down, centralised power to a bottom-up, decentralised public administration, and privatised many of the areas that were taken into public control in the post-war period (Hall, 2008). Government is often no longer unreservedly considered the principal actor in the policy arena and instead we have entered an era of 'governance' where there is an increased interest in the complex relations between government, business and civil society (UNWTO, 2013; Dredge, 2006; Rhodes, 1996). The term governance is used to describe the fragmentation of political authority, with areas (such as tourism) being regulated by specialised agencies rather than centrally coordinated ministries. While government is characterised by having centralised political structures that control resources, with a 'governance' approach the resources often remain dispersed among public and private actors who have to collaborate with each other in order to address common problems.

This shift from government to governance has been influenced by political rationales associated with a 'new right', 'corporatist' or 'neo-liberal' economic agenda which imply a 'laissez-faire' style of governance characterised by de-regulation and a market-led approach (Harvey, 2005). A principal economic reason for this shift is government's interest in reducing the dependency of public enterprises on public budgets. In contrast to the nationalisation of key functions, state assets are sold and functions that have historically been performed by government are commercialised in the hope of creating efficiencies and reducing public debt (Picketty, 2013). This changing role of government represents a dramatic change from a traditional public administration model which sought to implement government policy for a perceived public good, to a corporatist model which emphasises efficiency, investment returns, the role of the market, and relations with industry (Hall, 2011). Dredge and Jenkins (2007) explain that society is now better informed and people are more demanding; the idea that public spending is good has been widely rejected and the 'tax and spend' model of government is now out of favour. It is no longer assumed that government knows best when, where, and on what to spend tax-payers' money. As a result, new forms of interaction have emerged, with a less state-centric conception of the role of state in society. In this sense, the shift to governance can be associated with a reduction in the size of the state and a growing interdependence between public and private sector organisations (Cairney, 2012). The following section of this paper considers the implications of this broad shift for the tourism industry. 


\section{Governance and tourism}

Changes in government's role from provider to enabler under a more corporatist model have wide implications for tourism policy and destination management. It is useful to understand the changing nature of government's role in tourism as less of a direct action and more of a transition phase as there is often as many arguments from both the public sector and private sector to continue with some government control. On the one hand, the tourism industry can develop with less government interference, on the other hand, tourism industry interest groups will continue to lobby government to develop policy and make planning decisions in their favour (Hall, 1999). For instance, the lobbying activities of UKinbound, a trade association that represents the interests of the UK's inbound tourism sector, encourages government to continue funding destination marketing via Visit Britain, a publically funded national tourism agency (UKinbound, 2014), but would be unlikely to support any increase in regulations that affect their sector. It is for these reasons that the role of state in society, and therefore the relationship between state intervention and societal autonomy (or public authority and self-regulation), is a common focus of policy debate. Hall (2011) argues that despite the attention given in much contemporary literature on the rise of PPPs, for the most part the legislative and regulatory role of the state remains and a hierarchical governance model dominates. However, in this context, he acknowledges the variety of relationships that exist between public and private policy actors and the steering modes that range from hierarchical top-down to non-hierarchical approaches.

Hall (2011) developed a matrix of four governance typologies for tourism which he suggests can be used as an analytical tool, particularly in areas of policy and governance. The four frameworks are characterised by, and subsequently labelled as, hierarchies, markets, networks and communities. 'Hierarchies' is the traditional model of tourism governance with government as the principal actor, decision maker and funder. The role of 'markets' as a governance mechanism has been increasingly popular since the mid-1980s with the influence of neoliberal political philosophies regarding appropriate levels of state intervention in socio-economic systems (Harvey, 2005). In tourism this has been reflected in the corporatisation and privatisation of tourism functions that used to be the domain of the state (Shone and Memon, 2008). In this scenario, government does not cease to influence the market but it moves away from imposing regulatory mechanisms and towards other forms of intervention, such as financial incentives, education, or even guidance for self-regulation. However, market failure and other limitations associated with a market form of governance (e.g., equity of policy outcomes, sustainability, and 'free-riding') have been increasingly recognised (Crafts and Hughes, 2013; Hall, 2008). The UK Government Tourism Policy (DCMS, 2011) is illustrative of the difficulties in choosing to take a clear hierarchical versus markets governance approach by indicating the need for a reduction in the size and influence of the state and an emphasis on tourism businesses themselves being best placed to direct the marketing and development of tourism, whilst at the same time presenting a rationale for continued intervention based on the economic problems of free-riding and market failure (Kennell and Chaperon, 2013; DCMS, 2011). The third governance typology that Hall identifies is 'networks' which he explains can facilitate the coordination of public and private interests and resources. They vary widely in their organisation but PPPs are particularly common forms of network governance and this is often considered as a 'middle way' or 'third way' between hierarchical and market approaches to tourism governance (Giddens, 
1998). The extent to which networks may act to serve personal interests poses a major challenge for its utility as a policy instrument (Dredge, 2006). Finally, Hall identifies 'communities' as a governance framework, influenced by the demand for more direct citizen involvement in tourism governance. This framework has been criticized for being overly idealistic and exaggerating the benefits of perceived consensus, but nevertheless community participation remains an important issue for some countries (Hall, 2008).

\section{Management models for tourism destinations}

Theories of Governance critique the relationships between the state, corporations, non-governmental organisations and individuals; governance in this context encompasses the political, economic and administrative spheres of society. When examining the processes involved in destination management however, it is important to consider how these relationships are operationalised in practice, and how the various related enterprises are organised and coordinated (Eagles, 2009). Tourism governance can be highly politicised and this will strongly influence the management models used when managing tourism at destinations.

More (2005) examines the trend towards privatisation of public resources in the USA (public land in this instance), and proposes five different management models. These models reflect those commonly used for tourism destination management and marketing organisations. He first proposes a fully public model where the government agency operates all services. Second, there is the public utility model where the government agency operates as a private corporation. Thirdly is the outsourcing model which involves contracting out services to private companies. Next is the private, non-profit ownership where a non-government organisation is the owner and operator. Last, is the private, for-profit ownership model which involves ownership and operation by a private company. However, it is interesting to note that these categorisations do not adequately represent the growth of more specific PPP models in tourism in the UK.

Eagles (2009) evaluates a variety of management models for recreation and tourism partnerships in parks and protected areas and provides some useful insights into the benefits and limitations of these management models when governance criteria are applied. To do this, Eagles refers to Glover and Burton's (1998) typologies of institutional arrangements for the provision of recreation and tourism services. These are:

1 governmental arrangements whereby a public agency alone provides a public service

2 cross-sector alliances through contractual relationships between a public agency and a profit-making or not-for-profit organisation (e.g., partnerships and contracts)

3 regulated monopolies whereby a non-public organisation is granted a monopoly to directly provide public services (e.g., franchise)

4 divestiture whereby public services, lands or facilities are sold or leased to profit-making or not-for-profit agencies.

A governmental arrangement, such as the national parks model in the USA, is commended for being the most equitable approach for its citizens but criticised for high costs, limited flexibility and for being heavily bureaucratic (Crompton, 1999). It is important to recognise that the public and private sectors in a PPP will be expected to 
have different goals and will need to respond to different stakeholders (Wilson et al., 2009). Whilst some authors argue that only public ownership is appropriate and desirable if societal equity is to be achieved, others argue that only private sector operations can be financially efficient (see More, 2005). The third argument is that the answer lies somewhere in between, with PPPs demonstrating best practice (e.g., Heeley, 2011).

\section{Public-private partnerships}

Harvey [1989, as cited in Hall, (1999), p.280] recognised that "the new entrepreneurialism of the smaller state has, as its centrepiece, the notion of a 'PPP' in which a traditional local boosterism is integrated with the use of local government powers to try [to] attract external sources of funding, new direct investments, or new employment sources”. PPPs have dominated tourism policy development over the last two decades with varying levels of success, both in North America (Eagles, 2009) and more broadly in other western market led economies (Beaumont and Dredge, 2010).

PPPs are a contemporary mechanism by which private sector businesses enter into contracts with governments to deliver public services that have traditionally been delivered by the state. PPPs are probably most commonly associated with infrastructure projects (Hellowell and Vecchi, 2015; van den Hurk et al., 2015) but also in the delivery of education (Patrinos et al., 2009), transport (Albalate et al., 2015) and healthcare services (Acerete et al., 2015). PPPs are collaborative arrangements which can involve all or some elements of a project, i.e., from solely funding, to design, construction, operation and/or maintenance (Reeves, 2015; Ross and Yan, 2015). Based on her study of a PPP in Lake Macquarie, Dredge (2006) concludes that management strategies of this type for tourism will depend upon specific characteristics of the destination, the networks in operation and the actors and agencies involved.

As outlined earlier in this paper, it can be argued that an increase in the number of PPPs can be seen partly as a reaction to the movement towards privatisation that took place during the 1980s and 1990sand also again as a reaction to decreasing government budgets in light of the global financial crisis of 2008 (Acerete et al., 2015; Kennell and Chaperon, 2013). Governments have needed to find ways to provide public services that are more cost efficient and less of a burden on tax-payers' contributions (Dredge and Jenkins, 2007). Privatisation - the selling of state-owned assets to the private sector - is one way to do this, but it is argued that public services that are entirely in the hands of the private sector will operate purely with profitability in mind and without the social objectives that are traditionally expected of governments, i.e., the interests of the private sector are not aligned with those of government. PPPs are seen as a kind of 'trade-off' between the need for increased efficiencies which can be realised with the involvement of the private sector, whilst also allowing governments to retain some control over the service delivery which can ensure the protection of society's interests (Flinders, 2005). 


\section{The influence of 'islandness' on governance arrangements}

Baldacchino (2004) explains that the small size of the population and/or land area, coupled with isolation and 'islandness', can act to fuel distinctive politics. With 'islandness', there is the tendency for local politicians to safeguard and differentiate the island from external intervention. He further suggests that small islands are special because their 'geographical precision' facilitates a unique sense of place (Baldacchino, 2005). Similarly, Stratford (2008) suggests that islandness may be described as an affect of particular land- and water-scapes, valued for their special qualities and deemed worthy of protection as such. She argues that islands are constitutive of strong place-based identifications - emotional geographies that may be described as islandness. She proposes that island governments are engaged in processes of economic globalisation in ways that differ (at least in part) from continental counterparts. She also advances the idea that islandness moves people to value the special qualities of islands and protect them, often in response to globalisation and modernisation. She also argues that those who govern islands may be motivated or compelled to ignore, hide or 'fail to notice' the utility of islandness in their decision making processes, especially where the imperatives of economic development are prioritised in the polity and generate internal conflicts over possible futures. This last point was illustrated in her study of Tasmania, the only sub-national island state in the Australian federation, where research revealed that islandness did not inform Tasmanian debates during a period of significant economic, social and environmental discord, and that this failure to notice foundational emotional geographies of islandness in the conduct of government resulted in a failure to utilise the immense resourcefulness that such an ontological presence of islandness could provide. 'Islandness' is a relatively new concept that is emerging in the geography and island studies literature (Baldacchino, 2004), and this combination of governance and islandness presents a new way of understanding governance arrangements for tourism in SIEs.

\section{Tourism governance arrangements in the UK}

Although this paper focuses on an analysis of the introduction of a PPP for tourism in Jersey which is not part of the UK, politically it is a British Isle and is heavily influenced by the UK context. In the UK, new governance arrangements for tourism are commonly reflecting this shift from centralised Government control to a more shared approach with responsibility being transferred (to varying degrees) to the private sector. The current UK governance typology, at least where tourism is concerned, would probably match most closely with the characteristics of Hall's (2011) 'networks' category. Kennell and Chaperon (2013) in their analysis of the UK’s 2011 Tourism Policy (published by the Conservative-Liberal Democrat coalition party which was in power at that time) identified a neo-liberal ideology which placed a strong emphasis on tourism businesses to direct the development of the industry and to market the destination themselves. However, this 'markets' approach is undermined in the policy by the often prescriptive nature of the policy aims and also the continued justification for government intervention based on the problems associated with free riding and market failure. In the UK, as in most western countries, PPPs have been introduced as a central tool of governance within the wider modernisation agenda (Flinders, 2005) and local tourism collaborative marketing alliances between public and private sector organisations have become 
increasingly popular (Palmer, 1996). The drive towards PPPs for destination marketing, such as the high profile marketing campaign co-funded by Visit Britain and large tourism companies in the UK, demonstrates support for a 'networks' approach which allows government to continue to have a role to play in the future development of the UK's tourism industry, with increasing assistance from the private sector (Visit Britain, 2016).

The substantial literature on PPPs across a variety of policy fields indicates that they are not always the perfect solution to public policy problems, and that there are many obstacles to both their short-term and long-term success. For example, in the short-term it can be difficult to generate financial contributions from the private sector when this has not been required in the past. In the long-term, complex legal contracts necessary for PPPs mean that government's ability to adapt to changing circumstances, or to move assets and services back into public ownership is reduced (Ross and Yan, 2015).

\section{Jersey case study}

\subsection{Political characteristics of Jersey}

Jersey is the largest of the Channel Islands at $116 \mathrm{sq} . \mathrm{km}$ and is located $135 \mathrm{~km}$ from the south coast of England and $22 \mathrm{~km}$ from northwest France. Despite its location in the English Channel, Jersey is not part of the UK; it is a British Isle with its own autonomous local government called 'The States of Jersey' and with its own financial, legal and judicial systems (States of Jersey Statistics Unit, 2011a; This is Jersey, 2012). The UK is constitutionally responsible for the defence of the island, but Jersey has an international identity that is separate from that of the UK. The Island is not represented in the UK parliament, whose acts only extend to Jersey if expressly agreed by the Island that they should do so. Jersey is not part of the European Union but has a special relationship with it, being treated as part of the European Community for the purposes of free trade in goods (Jersey.com, 2012). Despite its proximity to the UK and French regions, there are fundamental social, political and economic differences between the island and its neighbouring mainlands, and the characteristics of its small island polities influence decisions about local governance arrangements.

\subsection{Economic characteristics of Jersey}

In 1971 tourism was the major industry in the island both in terms of its contribution to gross domestic product and to seasonal employment. It was estimated that vacation tourism expenditure made up 52\% of GDP and summer season employment in hospitality was $16.7 \%$. Banking and related activities were a relatively minor feature of the economy at that time, contributing 9\% of GDP and 3.3\% of total employment (Powell, 1997, as cited in Hampton and Christensen, 2007). However, during the 1970s and 1980s, the economy of Jersey saw a great deal of change, as trade markets became more international and global travel increased; traditional Jersey industries such as agriculture and tourism were superseded by financial services as the dominant industry in Jersey (Hampton and Christensen, 2007). In 2011, the financial services sector had grown such that it accounted for around two-fifths (41\%) of total gross value added (GVA), and for just under half (48\%) of all economic activity. Furthermore, it employed about a quarter of the island's workforce. The performance of the finance sector has clearly been central 
to the overall performance of the island's economy for at least the past decade and seems set to continue to do so (States of Jersey Statistics Unit, 2011a, 2011b).

\subsection{Significance of tourism in Jersey}

In Jersey's tourism heyday, in the 1970s and 1980s, Jersey used to enjoy annual leisure visitor numbers of just under one million (States of Jersey, 2014). However, Jersey is a now a post-mature (Gale et al., 2007) destination that has experienced a fairly steady decline in visitor numbers since this time. By the end of the 1990s, the total number of staying leisure visitors to the island was 590,000 per year, and this continued to fall up to the period of this research, when in 2012 the island received just 333,000 of these tourists (States of Jersey Statistics Unit, 2012). Registered tourist accommodation providers have also declined over recent years; in 2000 there were 236 registered accommodation properties (Thomas and Thomas, 2012) but by 2012 this had fallen to 140 (Jersey Tourism, 2012). This has mainly been as a result of the significant changes associated with tourism product development and distribution that have influenced Jersey's core market of UK tourists (Economic Development Department, 2009). Jersey's market appeal was mainly based on the traditional 'bucket and spade' two week summer holiday (BBC, 2006) but tourists' tastes and travel habits have changed since the 1990s when it became cheaper and easier for UK tourists to travel abroad (Page and Connell, 2014). Since then, Jersey has had to adapt to become a more sophisticated 'short break' destination to encourage more cosmopolitan, higher spending tourists, and to compete with European destinations such as Barcelona and Paris (BBC, 2006). For example, one recent objective for Jersey's DMO has been to develop event-led tourism to attract the growing European event tourism market (Thomas and Thomas, 2012).

According to the States of Jersey Statistics Unit (2011b), the contribution of the hotels, restaurants and bars sector to the Jersey economy was 3.5\% in 2010. This figure was lower than public administration (8.9\%), wholesale and retail (7.3\%), and construction (6.8\%), yet the tourism industry is commonly considered to be Jersey's second most important sector, after the finance sector. In 2010, Jersey received visitor numbers in the region of 685,000 and an estimated $£ 230$ million on-island visitor spend (Jersey Tourism, 2010). The contribution of tourism to Jersey's economy is more significant than the figure of $3.5 \%$ indicates. This low figure is likely to have been produced due to the specificities of the methodology used in its calculation, which has not calculated indirect investment and secondary spending to their full extents.

In 2006, a destination audit carried out by Locum Consulting concluded that Jersey had not kept up with the changing market conditions and recommended a need for radical change if the island is to exploit the current and future market trends. In addition to various recommendations related to product development, Locum Consulting (2006) identified the opportunity for the creation of a public-private DMO that could more effectively respond to market trends and make use of private sector resources.

\subsection{Governance and management arrangements for tourism in Jersey}

Jersey has had a public sector funded DMO since 1948. During the boom years, Jersey's DMO (Jersey Tourism) focused mostly on product development and regulation but this changed to a more marketing-focused role following the peak in tourism numbers in the 1970s (States of Jersey, 2014). At the end of the 1990s Jersey Tourism had a remit to 
market the destination, provide information to visitors, and to process accommodation bookings under the supervision of the Tourism Committee under the States of Jersey. This was funded entirely from the public purse and Jersey Tourism received £8.6 million in the year 2000. In 2004, the States of Jersey established the Tourism Development Fund; this fund was meant to provide an additional $£ 10$ million to the core funding to the DMO over a five year period, with the purpose of funding tourism product development in the island that was carried out by the private sector (Thomas and Thomas, 2012). However, due to a lack of suitable project bids a contribution of only £3.85 million was made in ten years of its operation (States of Jersey, 2014).

At the time of the study, the States of Jersey's Economic Development Department (EDD) was responsible for this same public-sector organisation, 'Jersey Tourism' (States of Jersey, 2012), which employed 18 full time employees, as well an additional 3 or 4 temporary, seasonal staff in visitor services (Jersey Evening Post, 2015).

Despite a budget reduction in 2011, tourism remained the single largest expenditure by the public sector, and over 35\% of the entire EDD net revenue expenditure budget and $33 \%$ of EDD staff resources were allocated to the tourism sector via this organisation (States of Jersey, 2011b). Despite a substantial allocation of resources, feedback from the consultations carried out by Locum Consulting (2006) revealed a widespread feeling in the industry that "Jersey Tourism is slightly out of touch with market reality and not quick enough on its feet” (p. 64), and that there seemed to be a case for a more integrated partnership approach to Jersey's tourism marketing function. Weaknesses of the organisational structure were identified as a lack of leadership of the tourism development function, a perception among stakeholders that the tourism industry could never reach agreement and was unable to respond effectively, that tourism development was not a political priority, and that the relationships between the Jersey Hospitality Association (JHA) and Jersey Tourism were not harmonious.

The main representative body of the industry, the JHA, instigated a move to a PPP as far back as 2005 and continued to support this idea as the best management option for the future of Jersey as a visitor destination (Jersey Hospitality Association, 2010). To be aligned with the States of Jersey Strategic Plan 2009-2014 objective of maintaining a strong, sustainable and diverse economy, the EDD (with the JHA) developed specific proposals to replace Jersey Tourism with a public-private organisation:

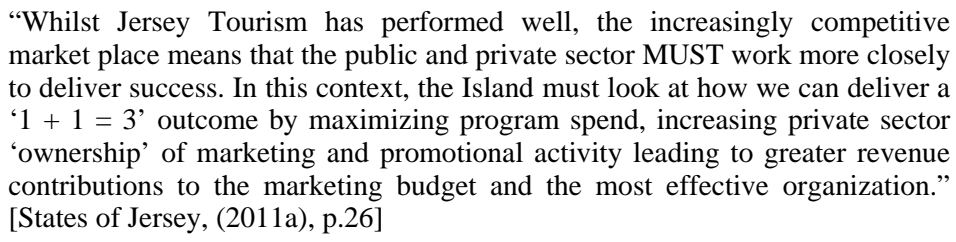

Flinders (2005) argues that as a tool of governance, PPPs can provide an influential mechanism (or even weapon) that ministers can wield over areas of the public sector that they perceive to be underperforming. 


\subsection{Proposals for PPP development in Jersey}

The PPP was proposed to be a non-profit-making company, limited by guarantee (Locum Consulting, 2007). The organisation would have an eight-member independent board comprised of a mix of public and private sector representatives, and led by a chairperson appointed by the Minister for Economic Development. It was hoped that the PPP would offer the opportunity to harness industry leading expertise, to encourage the private sector to work with EDD and other states departments to ensure government policy fully supports the growth of the tourism sector, to generate industry funding to add to Government investment, to encourage the marketing organisation to operate more commercially, to generate a stronger sense of partnership, and also to operate with a private sector culture which should deliver quicker and more effective decision making (Locum Consulting, 2006; EDD, 2009). To begin, the PPP would be funded entirely by EDD, with subsequent funding dependent on the PPPs ability to generate private funding, probably sourced from membership fees and corporate contributions.

An interesting element of the rationale for this PPP is the frequent reference made to the need for a 'unique' solution. Locum Consulting (2007) commented that the circumstances in Jersey were unusual due to the huge importance of the tourism industry in terms of direct and indirect employment that is disproportionate to the size of the population. The Minister for Economic Development, in his response to the PPP proposal, further highlighted Jersey's unusual situation and explained that there is a fundamental difference between Jersey and UK or French regions, in that as a result of the independence of the Island the many layers of international, national and regional activity have, by necessity, to be undertaken by the single agency, and as a result, "there is no single off-the-peg solution which can be copied from elsewhere” (p.4). EDD (2009) concluded that: "what is clear is that, whilst there are many different organisational models from which Jersey could learn, our circumstances are unique and will require a specific Jersey solution” (p.8).

In 2010, the proposal was examined by the States of Jersey Economic Affairs Scrutiny Panel who concluded that whilst a PPP had merit, given the economic climate and uncertainty about future budget levels the time was not right for implementation. Instead, a Tourism Marketing Panel was established as a 'middle way' partnership option. The Panel was made up of a variety of Jersey's key tourism stakeholders, an independent tourism expert, and was chaired by the CEO of the EDD. Its aim was to determine whether full PPP proposals require re-assessment in the future (Economic Affairs Scrutiny Panel, 2010). The economic growth strategy, published by the States of Jersey (2011a) during the study period, stated that by 1 January 2012 a new organisation, 'Visit Jersey', would be formed as a grant funded body, independent of government, with its own board, chief executive and staff structure. Despite this, by the end of the period under study, almost six years after the initial proposals for PPP were presented, no new organisational arrangements had been implemented for Jersey's tourism marketing, and discussions were ongoing. 


\section{Methodology}

This research took a qualitative case study approach to examine responses to proposed changes in governance arrangements for Jersey's tourism marketing function. Governance arrangements for tourism have not been studied before in this SIE context, and so a qualitative approach was considered most appropriate as it allows the researcher to illuminate the full extent of the subjects' accounts of a variety of phenomena (Flick, 1998). A case study strategy is employed which allows empirical investigation of a particular phenomenon within its real life context (Robson, 1993).

In 2012, primary data was collected in the form of telephone interviews. Interviews can facilitate the exploration of people's knowledge, views, understandings, interpretations and experiences. And, perhaps most importantly, they can provide fundamental insights into people's perceptions (Kvale, 2008). Interviewing was considered a particularly suitable method for this research as it assists one of the main aims; that are to understand people's perceptions of governance arrangements and decision making surrounding these issues for tourism in Jersey.

A purposeful sample (Ezzy, 2002) of five interview respondents was selected. The sample size is considered appropriate, considering the small size of the island and available pool of suitable respondents. The interview respondents were prominent representatives of the Jersey Tourism industry, covering travel, accommodation, and hospitality sectors. These respondents were well informed about the proposed governance arrangements as it affects their business, and thus well placed to discuss related issues. A larger sample would have been preferred, and this is a limitation of the study, but the timing of the data collection made this very difficult. Unbeknown to the researcher at the time, the data was collected in the same week as meetings were being held amongst the tourism industry lobby groups about this very issue and this meant that several potential respondents chose not to participate in the study.

The interviews, which lasted around one hour each, were recorded to enable repeated and detailed examination of the data. A semi-structured interview schedule was used as this allows the interviewee to develop ideas and elaborate on points that are of particular interest to them (Silverman, 2000). Respondents were asked for their views on the reasons for the proposed change in governance arrangements, the various PPP models that have been considered, the barriers to the PPP implementation, and the decision making processes that have surrounded the issue. A 'framework' approach, advocated by Ritchie and Spencer (1994) was employed for processing, sorting and analysing the data collected. In addition, for the purposes of the case study, a detailed examination of secondary sources was carried out, using the same framework approach, to identify issues for discussion in the primary data collection phase, and also to compare with the primary data, helping to achieve trustworthiness. These include documents published by the States of Jersey Statistics Unit, the States of Jersey EDD, Jersey Tourism, Jersey Hospitality Association, and also newspaper articles and blogs. 
Tourism industry responses to PPP arrangements for DMOs

\section{Discussion}

\subsection{Responses to the development of the proposed PPP}

There was a clear agreement amongst respondents from all sectors, supported by the majority of comments in the reports and articles analysed, that there was a general feeling of discontent with the effectiveness of the Jersey Tourism DMO. The main concerns raised were regarding Jersey Tourism's accountability and its ability to operate as a commercially-focused organisation, mainly because of the public sector culture in which it was ingrained. A local tour operator commented that, "a marketing organisation does not sit well in a civil service department. The two cultures are, to me, entirely different: This respondent also commented that outside of a public sector culture hiring and firing would be that much easier. The number of full-time employees at Jersey Tourism was often seen as a drawback to its efficacy, with one transport sector respondent suggesting too much budget is allocated to staffing and that an advantage of a PPP would be the ability to drive money to the sales end and away from the back office. In addition to the number, the expertise of employees was also brought into question. Respondents were not hugely critical of the Jersey Tourism staff, but there were some suggestions that they did not have sufficient tourism marketing experience. A representative from the hospitality sector commented that "the expertise that exists in a public sector environment, [it's] all very good, [with] professional managers, but not with the specialised skills that were necessary in this very specialised area”. This respondent suggested that with a PPP there would be the opportunity to use experienced and specialist professionals to execute the strategy, as opposed to generalists. Respondents further complained that due to the public-sector nature of the DMO, and almost guaranteed annual budgetary allocations; it was not fully accountable for the outcomes of its spending. Two other PPPs have been established in Jersey - The Jersey Conference Bureau and Jersey Finance - and respondents often referred to these as success stories. A private-sector led organisation was considered much better able to operate commercially and with the appropriate expertise.

\subsection{Perceived barriers to implementation of a PPP}

The key perceived barriers to implementation of the PPP were related to funding and political support, staffing, and island characteristics or 'islandness'.

Because Jersey's DMO is government's responsibility, the organisation enjoys reduced or no charges for overheads such as IT support, rent, and other utilities. One respondent commented that the organisation needs to move away from the 'umbilical cord' of the States of Jersey and be self-sufficient. Being outside a states department obviously means that a significant increase in industry funding will be required to offset some of the additional administration and service costs, but respondents hoped that this would be later offset by the increased efficiencies realised by the PPP once in full operation. A more pressing concern was the uncertainty surrounding continued public sector investment, and this was linked to the perception that there is a lack of political support for Jersey's tourism industry. The Economic Affairs Scrutiny Panel (2010) highlighted that "the falling trend of the Jersey Tourism budget demonstrates a questionable political commitment to the Tourism industry” (p. 5), and a local hospitality sector representative argued that the proposed PPP has just simply not received the 
political drive to drive it to completion. A frequently cited reason for this 'neglect' is the strong competition between the finance and tourism industries in the island. A tourist accommodation stakeholder explained:

"We've been trying to make out that finance is the be all and end all, therefore the island should jump through hoops to benefit the finance industry rather than any other local industries on the island ... [tourism] has been seen as rather a poor relation."

Hampton and Christensen (2007) explore the nature of the relationship between tourism and offshore finance in Jersey, Channel Islands, and examine the different growth dynamics of the two industries. It has been suggested by policy-makers on islands that a positive, even symbiotic, relationship can exist between finance and tourism (Powell, 1971, as cited in Hampton and Christensen, 2007). The two industries do share several characteristics, such as high mobility, rising global demand, labour-intensive customer services operations, and a reliance on advanced transport and telecommunications infrastructure. In fact, for Jersey (unlike most UK resorts) the growth of the financial services industry helped the tourism industry in that it created demand for residential accommodation that soaked up obsolete tourist accommodation (Locum Consulting, 2006) and also generated a new 'business tourist' market. But, Hampton and Christensen (2007) suggest that beyond a certain stage of development, the link between the finance and tourism industries becomes one of intense competition for scarce resources. This feeling of intense competition, rather than complementarity of the two industries, is strongly felt by respondents in the Jersey case.

Respondents also voiced concerns about the ability of the private sector to generate sufficient financial contribution to a PPP DMO budget. The Economic Affairs Scrutiny Panel (2010) warned that whilst the PPP would receive funding from the EDD at a level equivalent to its usual budget expenditure, this funding would be dependent upon the PPP's ability to generate a significant level of private funding which in turn would secure the public financial support on an ongoing basis. There were worries that the private sector may struggle to do this in the troubled economic conditions at that time. Respondents also expressed concerns that the private sector would not be keen to contribute financially to the PPP as you would commit a sum of money over which you then had very little, if any, concrete say over how it was spent. This supports Wong et al.'s (2012) conclusion, in their study of PPPs in the small island of Samoa, that there needs to be a certain level of trust established between the public and private sectors in order to facilitate the formation of PPPs.

Staffing issues were identified as another key barrier to successful implementation of the PPP: "there were clearly going to be some major problems devolving staff from a government run civil service department into a commercial organisation”. It was anticipated that many members of the existing Jersey Tourism team would transfer to the PPP and this raises issues associated with employment rights and the UKs Transfer of Undertakings Protection of Employment, commonly known as TUPE. Although TUPE is not directly applied in Jersey, it was often proposed that employees should be transferred to their new employee under the same terms and conditions. However, there may not be an equivalent role for a Jersey Tourism employee in the new PPP, and in such cases it would be inappropriate for the states to require that person to transfer. Instead, the states should offer alternative suitable employment (EDD, 2009). The conflict between the employment rights of public sector employees and the private sector culture of striving to 
reduce costs through staffing efficiencies became a sticking point in the decision making process.

A further barrier to the successful implementation of the PPP was less easy to define, but is described here as issues associated with 'islandness' (Baldacchino 2004; Stratford, 2008). As with many islands, due to the small size of the island of Jersey and the relatively small population, Government tends to be omnipresent and the local people tend to be closer to politicians than might be the case on the mainland. For example, a

Jersey tour operator acknowledged that, "there is no doubt that in a geographic area of 45sq. miles you're obviously much more aware of everything that's going on that you might be if you were in 450,000 sq. miles" and added that, "I suppose the closeness of individuals within government to the private sector is an issue, yes". It was suggested that the public sector decision-makers were reluctant to make changes to the structural arrangements for Jersey's DMO because the changes were not supported by employees and that "it has been more about maintaining the status quo". A second characteristic of 'islandness' that was apparent in the interviews was the importance given to public opinion in local media. A local hotelier commented that "it's a bit of an odd thing in Jersey that you write two letters to the Jersey Evening Post and then that changes government policy!:

\section{Conclusions}

This paper has examined tourism industry stakeholders' responses to a PPP proposal for Jersey's DMO. It is clear that there is support from the industry for a more private sector-led organisation, but there is uncertainty about the ability of the private sector to contribute sufficient investment, and an expectation that the public sector will guarantee continued investment. The issue of transferring staff from a public to a private sector organisation is a key barrier to the PPP's implementation, and the feeling is that this issue is exacerbated by the small size of the island and the personalised nature of politics. Argument has been made that an 'off-the-peg' PPP model can not be applied to Jersey as its characteristics mean that it requires a unique solution, yet after several years of discussion and debate the PPP model proposed is fairly standard and similar to those applied in the UK. It seems that it is not necessarily the type of PPP model that warrants attention, but rather there is the need for the public sector to conclude the decision making process and to drive forward to the implementation phase. It is the characteristics associated with 'islandness' that are influencing the type of proposed organisational arrangements, but in particular it is the nature of small island polities that is affecting the opportunity for change.

This study uses governance theory as an approach to understanding how tourism is managed in an island destination and it also contributes to the limited literature on 'islandness' in a tourism and governance context. SIEs that are tourist destinations are frequently dependent on tourism for the development of their local economies and the public sector often takes the lead in driving and managing the industry, preferring Hall's (2011) 'hierarchical' approach to tourism governance. The results of this study may be useful for SIEs that are entering phases of transition from top down models to partnership options. In particular, the study has revealed that there may be resistance from the industry to generic PPP models of governance that do not take into account local manifestations of islandness. An awareness of this added layer of complexity in decision 
making about governance arrangements, and taking into consideration the likely concerns from the industry in SIEs can help governments to more fully consider the specificities that will be required and to present a more suitable PPP option in earlier stages of the process, generating more industry support from the beginning and improving the likelihood that such PPP proposals can be implemented in a timely and efficient manner.

\section{References}

Acerete, B., Gasca, M., Stafford, A. and Stapleton, P. (2015) 'A comparative analysis of healthcare PPPs: examining evidence from two spanish regions from an international perspective', Journal of Comparative Analysis, Vol. 17, No. 5, pp.502-518.

Albalate, D., Bel, G., Bel-Piñana, P. and Geddes, R. (2015) 'Risk mitigation and sharing in motorway PPPs: a comparative policy analysis of alternative approaches', Journal of Comparative Policy Analysis, Vol. 17, No. 5, pp.481-501.

Baldacchino, G. (2004) 'Autonomous but not sovereign?: a review of island sub-nationalism', Canadian Review of Studies in Nationalism, Vol. 31, Nos. 1-2, pp.77-89.

Baldacchino, G. (2005) 'The contribution of 'social capital' to economic growth: lessons from island jurisdictions', The Round Table, Vol. 94, No. 1, pp.31-46.

BBC (2006) Talking Jersey [online] http://www.bbc.co.uk/jersey/content/articles/2006/11/24/ tourism_short_break_feature.shtml (accessed 30 January 2015).

Beaumont, N. and Dredge, D. (2010) 'Local tourism governance: a comparison of three network approaches', Journal of Sustainable Tourism, Vol. 18, No. 1, pp.7-28.

Bramwell, B. (2011) 'Governance, the state and sustainable tourism: a political economy approach', Journal of Sustainable Tourism, Vol. 19, Nos. 4-5, pp.459-477.

Bramwell, B. and Lane, B. (2010) 'Sustainable tourism and the evolving roles of government planning’, Journal of Sustainable Tourism, Vol. 18, No. 1, pp.1-5.

Bramwell, B. and Lane, B. (2011) 'Critical research on the governance of tourism and sustainability', Journal of Sustainable Tourism, Vol. 19, Nos. 4-5, pp.411-421.

Cairney, P. (2012) Understanding Public Policy: Theories and Issues, Palgrave Macmillan, London.

Commonwealth Secretariat (1997) A Future for Small States: Overcoming Vulnerability, Commonwealth Secretariat, London.

Crafts, N. and Hughes, A. (2013) Industrial Policy for the Medium to Long-Term. Future of Manufacturing Project: Evidence Paper 37, Foresight, Government Office for Science, London.

Crompton, J.L. (1999) Financing and Acquiring Park and Recreation Resources, Human Kinetics, Champaign, IL.

DCMS (2011) UK Government Tourism Policy, HMSO, London.

Dredge, D. (2006) Policy networks and the local organisation of tourism', Tourism Management, Vol. 27, No. 2, pp.269-280.

Dredge, D. and Jenkins, J. (2007) Tourism Planning and Policy, Wiley, Australia.

Eagles, P. (2009) 'Governance of recreation and tourism partnerships in parks and protected areas', Journal of Sustainable Toursim, Vol. 17, No. 2, pp.231-248.

Economic Affairs Scrutiny Panel (2010) Tourism Public Private Partnership. S.R.8./2010, States of Jersey, Jersey.

Economic Development Department (2009) Discussion Paper on the Development of a Public Private Partnership (PPP) for the Marketing and Promotion of Jersey as a Visitor Destination. Version 7 - 23 December 2009, States of Jersey, St Helier.

Ezzy, D. (2002) Qualitative Analysis, Practice and Innovation, Routledge, London. 
Flick, U. (1998) An Introduction to Qualitative Research, Sage, London.

Flinders, M. (2005) 'The politics of public-private partnerships', The British Journal of Politics and International Relations, Vol. 7, No. 2, pp.215-239.

Gale, T., Argawal, S. and Shore, G. (2007) 'The problems and dilemmas of northern European post-mature coastal tourism resorts', in Argawal, S. and Shore, G. (Eds.): Managing Coastal Tourism Resorts: A Global Perspective, Channel View Publications, Clevedon.

Giddens, A. (1998) The Third Way: The Renewal of Social Democracy, Polity Press, Cambridge.

Glover, T.D. and Burton, T.L. (1998) 'A model of alternative forms of public leisure services delivery', in Collins, M.F. and Cooper, I.S. (Eds.): Leisure Management: Issues and Applications, pp.139-155, CABI, New York.

Hall, C.M. (1999) 'Rethinking collaboration and partnerships', Journal of Sustainable Tourism, Vol. 7, Nos. 3-4, 274-289.

Hall, C.M. (2008) Tourism Planning: Policies, Processes and Relationships, Prentice Hall, Harlow.

Hall, C.M. (2011) 'A typology of governance and its implications for tourism policy analysis', Journal of Sustainable Tourism, Vol. 19, Nos. 4-5, pp.437-457.

Hampton, M. and Christensen, J. (2007) 'Competing Industries in Islands: new tourism approach', Annals of Tourism Research, Vol. 34, No. 4, pp.998-1020.

Harvey, D. (2005) A Brief History of Neo-Liberalism, Polity, Cambridge.

Heeley, J. (2011) 'Public: private partnership and best practice in urban destination marketing', Tourism and Hospitality Research, Vol. 11, No. 3, pp.224-229.

Hellowell, M. and Vecchi, V. (2015) 'The non-incremental road to distaste? A comparative policy analysis of agency problems in the UK and Italy', Journal of Comparative Policy Analysis, Vol. 17, No. 5, pp.519-532.

Jersey Evening Post (2015) States Deny 18 Staff Axed in Visit Jersey Transition - Full Background on the Organisation Taking Over Jersey Tourism This Month [online] http://jerseyeveningpost.com/news/2015/03/04/states-deny-18-staff-axed-in-visit-jerseytransition-full-background-on-the-organisation-taking-over-jersey-tourism-this-month/ (accessed 27 August 2016).

Jersey Hospitality Association (2010) Hospitality Group Enthusiastically Supports the Creation of a New Public Private Sector Partnership for the Future Marketing and Promotion of Jersey as a Visitor Destination, 3 February [online] http://www.jerseyhospitality.com/newsletters/doc download/45-jha-business-update-february-2010 (accessed 10 July 2012).

Jersey Tourism (2010) A Year in Review 2010, Jersey Tourism, Jersey.

Jersey Tourism (2012) A Year in Review 2012, Jersey Tourism, Jersey.

Jersey.com (2012) People and Government [online] http://jersey.com/English/aboutjersey/ theisland/peopleandgovernment/Pages/default.aspx (accessed 20 May 2012).

Jessop, B. (2003) From Thatcherism to New Labour: Neo-Liberalism, Work Farism, and Labour Market Regulation, Department of Sociology, Lancaster University [online] http://www.comp.lancs.ac.uk/sociology/soc131rj.pdf (accessed 27 August 2016).

Kennell, J. (2013) 'New developments in the relationships between tourism policy and local economic development in the United Kingdom', International Journal of Hospitality and Tourism, Vol. 3, No. 2, pp.59-69.

Kennell, J. and Chaperon, S. (2013) 'Analysis of the UK government's 2011 tourism policy', Cultural Trends, Vol. 22, No. 2, pp.278-284.

Kooiman, J. (2000) 'Levels of governing: interactions as a central concept', in Pierre, J. (Ed.): Debating Governance, Oxford University Press, Oxford.

Kvale, S. (2008) Doing Interviews, Sage, London.

Laws, E., Richins, H., Agrusa, J. and Scott, N. (2011) Tourist Destination Governance: Practice, Theory and Issues, CABI, Wallingford. 
Locum Consulting (2006) Jersey Destination Audit - Towards a Jersey Tourism Development Strategy. November 2006, Locum Consulting, Haywards Heath.

Locum Consulting (2007) Marketing Jersey. Organisational Plan. Final Report - Version 4. September 2007, Locum Consulting, Haywards Heath.

More, T. (2005) 'From public to provate: five concepts of park management and their consequences', Privatization: An Overview, Vol. 22, No. 2, pp.12-20.

Mosedale, J. (Ed.) (2011) Political Economy, Routledge, London.

Page, S. and Connell, J. (2014) Tourism: A Modern Synthesis, 4th ed., Cengage, London.

Palmer, A. (1996) 'Linking external and internal relationship building in networks of public and private sector organizations: a case study', International Journal of Public Sector Management, Vol. 9, No. 3, pp.51-60.

Patrinos, H.A., Barrera-Osorio, F. and Guáqueta, J. (2009) The Role and Impact of Public Private Partnerships in Education, The World Bank, Washington, DC.

Picketty, T. (2013) Capital in the Twenty-First Century, TJ International Ltd, Padstow.

Reeves, E. (2015) 'A review of the PPP experience in Ireland: lessons for comparative policy analysis', Journal of Comparative Policy Analysis, Vol. 17, No. 5, pp.467-480.

Rhodes, R.A.W. (1996) 'New governance: governing without government', Political Studies, Vol. 44, No. 4, pp.652-667.

Richards, D. and Smith, M.J. (2002) Governance and Public Policy in the UK, Oxford University Press, Oxford.

Ritchie, J. and Spencer, L. (1994) 'Qualitative data analysis for applied policy research', in Bryman, A. and Burgess, R. (Eds.) Analyzing Qualitative Data, pp.173-194, Routledge, London.

Robson, C. (1993) Real World Research, Blackwell, Oxford.

Ross, T.W. and Yan, J. (2015) 'Comparing public-private partnerships and traditional public procurement: efficiency vs flexibility’, Journal of Comparative Policy Analysis, Vol. 15, No. 5, pp.448-466.

Shone, M. and Memon, A. (2008) 'Tourism, public policy and regional development: a turn from neo-liberalism to the new regionalism', Local Economy, Vol. 23, No. 4, pp.290-304.

Silverman, D. (2000) Doing Qualitative Research. A Practical Handbook, Sage, London.

States of Jersey (2011a) Jersey - A New Economic Growth Strategy: Quality of Life Through Economic Success. Policy Under Development, States of Jersey, Jersey.

States of Jersey (2011b) Annex to Annual Business Plan 2011, States of Jersey, St Helier.

States of Jersey (2012) Who We Are and What We Do [online] http://www.gov.je/Government/ Departments/EconomicDevelopment/Pages/WhoWeAre.aspx (accessed 10 July 2012).

States of Jersey (2014) Preliminary Report of the Tourism Shadow Board, States of Jersey, St Helier.

States of Jersey Statistics Unit (2011a) Jersey in Figures 2011, States of Jersey, St Helier.

States of Jersey Statistics Unit (2011b) Jersey Gross Value Added (GVA) and Gross National Income (GNI) 2010, States of Jersey, St Helier.

States of Jersey Statistics Unit (2012) Jersey in Figures, States of Jersey, St Helier.

Stratford, E. (2008) 'Islandness and struggles over development: a Tasmanian case study', Political Geography, Vol. 27, No. 2, pp.160-175.

This is Jersey (2012) Government [online] http://www.thisisjersey.com/island-life/laws-andadmin/government/ (accessed 10 July 2012).

Thomas, B. and Thomas, S. (2012) 'Cultural events and tourism in Jersey', Shima: The International Journal of Research into Island Cultures, Vol. 16, No. 1, pp.114-131. 
UKinbound (2014) UKinbound Lobbies the Government Before Budget 2014 [online] http://www.ukinbound.org/news/n/2014/mar/14/ukinbound-lobbies-the-government-beforebudget-2014 (accessed 3 April 2014).

UNWTO (2013) Governance for the Tourism Sector and its Measurement, United Nations World Tourism Organisation (UNWTO), Madrid.

van den Hurk, M., Brogaard, L., Lember, V., Petersen, O.H. and Witz, P. (2015) 'National varieties of public-private partnerships (PPPs): a comparative analysis of PPP-supporting units in 19 European countries, Journal of Comparative Policy Analysis, Vol. 18, No. 1, pp.1-20.

Visit Britain (2016) Campaigns [online] https://www.visitbritain.org/campaigns (accessed 3 January 2016).

Wilson, E., Nielsen, N. and Buultjens, J. (2009) 'From lesses to partners: exploring tourism public-private partnerships within the New South Wales national parks and wildlife service', Journal of Sustainable Tourism, Vol. 17, No. 2, pp.269-285.

Wong, E., de Lacy, T. and Jiang, M. (2012) 'Climate change adaptation in tourism in the South Pacific - potential contribution of public-private partnerships', Tourism Management Perspectives, Vol. 4, pp.136-144. 